\title{
整
}

\section{Kloning: konflik tussen wat kan en wat mag. 'n Voorlopige ondersoek vanuit teologies-etiese perspektief}

\author{
J.H. van Wyk \\ Skool vir Kerkwetenskappe \\ Potchefstroomse Universiteit vir $\mathrm{CHO}$ \\ POTCHEFSTROOM \\ E-pos: rtsnb@puknet puk ac.za
}

\begin{abstract}
Cloning: Conflict between what can and what ought. A provisional investigation from a theological-ethical perspective

It surely is not an overstatement to say that the first successful cloning of a sheep in 1997 in Scotland can be described as a Copernican revolution not only in medical ethics but also in man's world view. The question thus arises how long it will eventually take before a human being will be cloned. This issue, however, foregrounds the ethical concern of whether a process that scientifically can be implemented and a result that can be achieved, always ought to be executed. Of course there are many pro's as far as the cloning of a human being is concerned, but what about the con's? Focusing on this specific issue, it is attempted to find a provisional answer from a theological-ethical point of view.
\end{abstract}

\section{Problematisering}

"Not since God took Adam's rib and fashioned a helpmate for him has anything so fantastic occurred", skryf Krauthammer (1997:46) in Time na aanleiding van die eerste suksesvolle kloning van die Dorset-ooi Dolly deur $\mathrm{dr}$. Ian Wilmut en sy span wetenskaplikes by die Roslin Instituut (naby Edinburgh) in Skotland. Kloning is al vergelyk met 'n Kopemikaanse revolusie en atoomsplitsing en daar word beweer dat dit die wêreldbeskouing van die moderne mens op 'n ingrypende wyse sal verander (De Knijff, 1997:255). Skaars 'n jaar na Wilmut se deurbraak het die Amerikaner, dr. Richard Seed, 'n verklaring uitgereik dat hy mense gaan kloon met die doel om kinderlose egpare te help (vgl. Beeld, 10-011998:7; vgl. ook Rorvik, 1978). 
Dit is belangrik om tussen kloning en splyting te onderskei (vgl. Macklin, 1994:209-225; Cohen \& Tomkin, 1994:193-203; Robertson, 1994:6-14; Van Niekerk, 1994:24-25). Splyting van (gewone) embrio's by diere is reeds lankal praktyk, maar kloning van selle wat nie embrioties is nie, is 'n volkome nuwe ontwikkeling. Die splyting van skaapembrio's het reeds in 1979 geslaag en dié op beeste in 1980 (Rae, 1996:172), terwyl Hall en Stillman in 1983 'n menslike embrio die eerste keer suksesvol gesplyt het (Rae, 1996:169). Die Roslinnavorsers het hulle later skerp teen die kloning van mense uitgespreek, maar oor die moontlikheid daarvan bestaan weinig twyfel. Daarmee is die (mediese) etiek in 'n nuwe krisis gedompel. "Wilmut will spawn more ethics conclaves than cloned sheep", het Krauthammer in die genoemde artikel in Time opgemerk.

Inderdaad het die mediese tegnologie reeds sulke duiselingwekkende hoogtes bereik dat dit die etiek, ook die Christelike etiek, met 'n geweldige agterstand gelaat het. Dit is natuurlik nie so dat daar glad nie - vroeër' ${ }^{1}$ en resent ${ }^{2}$ - oor medies-etiese kwessies besin is nie, maar die tendens was steeds dat die mediese kompetensie altyd verder onder die mediese etiek uit beweeg het. Wat kan het die oorwig gekry oor wat mag, kompetensie oor behorenseis. Die eerste nierdialise (1960) en die eerste hartoorplanting (1969) het die vraagstelling oor (mediese) kompetensie en (morele) behorenseis verskerp (Van Niekerk, 1997). Die vraag na die grense van kompetensie is "een van die dringendste vrae op die hedendaagse geneeskundige toneel" (Van Niekerk, 1997:260).

Die mag van die mediese tegnologie tree duidelik aan die lig by vrae rondom die begin van lewe (kunsmatige bevrugting en surrogasie), by die verbetering van lewe (transplantasie en kloning), asook by die beëindiging van lewe (aborsie en eutanasie).

Die vrae rondom genetiese manipulasie in die algemeen en kloning in die besonder is waarskynlik van die heel moeilikste waarmee die etiek te doen het. Die moontlikhede wat daarmee geopen word, is fenomenaal. Dit is immers byna onvoorstelbaar dat ' $n$ seun sy pa se identiese tweelingbroer kan wees (Smit, $1985: 167)$ en dat 'n pa 'n hele aantal identiese seuns kan hê, met byna niks van die moeder in hulle nie (Smit, 1985:167). Word Aldous Huxley (1932) se fiksie van 'n verbeterde - gehominiseerde - mens dalk 'n feit?

Die vraag moet tans beantwoord word wat onder kJoning verstaan moet word.

1 Vgl. Lindeboom, 1960; Taylor, 1968; Van den Berg, 1969; Sporken, 1969; Leach, 1970; Smith, 1970; Van Wyk, 1971; Ouweneel, 1975, Rorvik, 1978; Ebon, 1978

2 Vgl. Beauchamp \& McCullough, 1984; Nelson \& Rohricht, 1984; Singer \& Wells, 1984; De Beaufort \& Dupius, 1988, Beauchamp \& Childress, 1989; Jonsen, 1990; Feindberg \& Feindberg, 1993; Dixon, 1993; Rae, 1996, Meilander, 1997 


\section{Definiëring}

Kloning (afgelei van die Griekse woord kloneoo wat onder andere verdeel beteken) kan beskryf word as daardie proses waarvolgens 'n eisel van sy kem ontdaan en deur middel van kerntransplantasie vervang word met die kern van 'n gespesialiseerde liggaamsel van 'n skenkerorganisme (vgl. Smit, 1985:167; De Beaufort \& Dupius, 1988:434; Douma, 1989:134; Feindberg \& Feindberg, 1993: 249; Robertson, 1994:6). Anders gesê: "The nucleus of a mature but infertilized egg is removed (by microsurgery or by irradiation) and replaced by a nucleus obtained from a specialized somatic cell of an adult organism (e.g., an intestical cell or a skin cell)" (Nelson \& Rohricht, 1984:135, met verwysing na L.R. Kass). Onder kloning word verstaan die vermoë om identiese kopieë van genetiese materiaal te vervaardig (Scorgie \& Jones, 1997:665). Dit is dus 'n vorm van aseksuele reproduksie ${ }^{3}$ (soos by die stervis aangetref word). Trouens, selfs die pa kan uitgeskakel word indien 'n liggaamsel van die ma gebruik word.

By Dolly het die proses soos volg verloop (Nash, 1997:50-51): selle is geneem van die nier van 'n dragtige Dorset-ooi en vir 'n week lank laat "verhonger". Ondertussen is 'n onbevrugte eisel (oösist) van 'n Skotse Swartkop-ooi geneem en die kem (met sy DNA) daarvan uitgesuig. Vervolgens is die twee selle na mekaar gebring en met 'n ligte elektriese skok behandel, waarop die twee kerne geheg het; 'n tweede skok het seldeling aan die gang gesit. Ses dae later is die embrio in die uterus van 'n ander Swartkop-ooi geplaas en op die bestemde tyd is Dolly gebore - geneties identies met die oorspronklike Dorset-ooi!

Indien daar geslaag word om mense te kloon, sal sodaniges volkome identies wees aan die persoon van wie die nuwe kem afkomstig is, aangesien elke sel die totale genetiese bloudruk van die liggaam bevat (Smit, 1985:167; Feindberg \& Feindberg, 1993:249). Trouens, alle selle in die liggaam, behalwe vir rooibloedselle en saadselle, bevat ' $n$ identiese nukleus wat op sy beurt al die gene van 'n persoon bevat (Dixon, 1993:45). Deur middel van kloning is dit moontlik om 'n groot aantal mense te produseer wat identies is. Somattese identiteit impliseer egter nie noodwendig psigiese identiteit nie, aangesien laasgenoemde medebepaal word deur opvoeding, ervaring en talle omgewingsfaktore. Persoonlike identiteit ontwikkel met verloop van tyd, sodat 'n persoon uiteindelik veel meer is as die somtotaal van sy gene (vgl. Rae, 1996:171, 178, 181, Feindberg \& Feindberg, 1993:252). Alle karaktertrekke is nie bloot geneties manipuleerbaar nie. Aan die ander kant toon identiese tweelinge, wat in verskillende gesinne groot geword het, buitengewoon groot ooreenkomste ten opsigte van ontwikkeling, kleredrag,

3 Ek merk hier terloops op dat die inkarnasie en die maagdelıke geboorte van Christus dus nie noodwendig 'n onsinnige gedagte is nie, al wil ek geensins beweer dat hierdie geheim op (so) in rasionele wyse deursigtig gemaak kan word nue. 
musiek en stokperdjies (Dixon, 1993:50). (Identiese tweelinge het 'n volkome identiese genetiese kode en is splytings van mekaar - Dixon, 1993:52.)

Die volgende vraag wat ons aandag vra, gaan oor die voordele van kloning. Bevoordeel kloning nie humaniteit en los dit nie probleme rondom kinderloosheid op nie?

\section{Positivering}

Verskillende navorsers (vgl. Smit, 1985:167; Nelson \& Rohricht, 1984:135-136; Feindberg \& Feindberg, 1993:249-250; Scorgie \& Jones, 1997:675-678) wys op 'n wye reeks (oënskynlike) positiewe aspekte wat aan kloning verbonde is. Die volgende kan in hierdie verband genoem word:

- Kloning bied 'n alternatiewe opsie in reproduksie en oorbrug probleme rondom infertiliteit - en lewer sodoende 'n bydrae tot groter vroue-vryheid.

- Kloning bied geleentheid om die kwaliteit van die genotipe te waarborg.

- Kloning maak dit moontlik dat die genotipe, geslagtelikheid en karakter van kinders bepaal kan word.

- Kloning bied die geleentheid dat 'n identiese embrio gevries kan word en indien ' $n$ kind vroeg sterf, kan die bevrore embrio ontwikkel word en sodoende kan die gestorwe kind met 'n identiese kind vervang word (vgl. Dixon, 1993:50). (Maar wat van die (skrikwekkende) gedagte dat 'n tiran hom graag sal wil dupliseer - Dixon, 1993:51?)

- Kloning maak dit moontlik om genetiese tekorte en siektes by die nageslag uit te skakel.

- Kloning skep die moontlikheid dat die lewenservaring wat die selskenker oor jare opgedoen het, geneties na sy biologiese identikaat oorgedra kan word.

- Kloning skep geleentheid dat genieë (soos Einstein en Beethoven) herhaal kan word en dat spesiale persone vir spesiale take gekweek kan word.

- Kloning bied 'n beter alternatief as (die onderhoud van) spermbanke.

- Kloning kan weefselverwerping in geval van orgaanoorplantings by gekloneerdes uitskakel en 'n bron van orgaanoorplantings wees. Dit is teoreties moontlik "to have a semi-specialised cell developed from a fertilised egg and treat it in the laboratory so that it reacts to form, say, a perfect replacement kidney" (Dixon, 1993:53). 
Op die oog af lyk dit na 'n formidabele reeks voordele. Wat egter in die bogenoemde voorbeelde ontbreek, is die vraag of kloning moreel verantwoord is. Mág, wat kán? Is daar vanselfsprekend permissie waar kompetensie aanwesig is? Is wat moontlik is ook behoorlik? Hoe lê die verhouding tussen (mediese) tegnologie en etiek? Op hierdie vrae sal veral in punt 5 aandag bestee word, maar daar kan nou reeds bepaalde vrae vanuit die bio-etiek gestel word.

\section{Negativering}

Die volgende probleme word deur navorsers in hierdie verband genoem (vgl. Nelson \& Rohricht, 1984:136-137; Feindberg \& Feindberg, 1993:250-252; De Knijff, 1997:255-258; Scorgie \& Jones, 1997:666-668):

- Daar is allereers die biologiese probleem dat skadelike gene in die genepoel teregkom en kan bydra tot 'n degenerasie van die menslike genepoel. Kloning verminder genetiese diversiteit - wat moet gebeur as kloning 'n mislukking is en wanstaltige mense gebore word? Indien die liggaamsel van 'n infertiele persoon (man of vrou) gebruik word, word die infertiliteit gekontinueer en sal 'n samelewing later net deur kloning kan voortbestaan.

- Daar is voorts sosiale probleme, soos dat kloning die insidensie van genetiese siektes in 'n bevolking kan vermeerder - natuurlike seksuele produksie verseker, meer as by gekloneerdes, aanpassing by veranderde omstandighede.

- Daar is verder ook wetlike probleme, byvoorbeeld dat kloning (nog) nie in alle lande (bv. Engeland) gewettig is nie. Hoe kan 'n skuldige ooit vasgetrek word as pa en seun dieselfde vingerafdrukke het?

Hierby kan 'n hele reeks morele probleme gevoeg word, byvoorbeeld:

- Bring kloning nie ouerskap en die gesin as instituut in gedrang nie?

- Sal kloning nie enkel-ouerskap promoveer nie?

- Sal dit nie surrogasie vermeerder nie?

- Sal dit nie 'n skenker se individualiteit bedreig nie?

- Sal dit nie die gekloneerde persoon se waardigheid bedreig nie, omdat 'n unieke genotipe ontbreek?

- Sal die medikus nie gedehumaniseer word nie?

- Wat van die dood van embrio's by inplanting? (vgl. Du Toit, 1989:101-111; Smit, 1991:313-337). 
- Mag daar hoegenaamd op hierdie wyse met menslike lewe geëksperimenteer word?

Uiteindelik is daar die groot godsdienstige vraag: Speel die mens nie God nie? Doen hy nie wat God gedoen het nie, naamlik om 'n mens na sy beeld te skep?

Dit is begryplik dat daar, gesien al bogenoemde probleme, deur etici hoofsaaklik negatief oor kloning geoordeel word, en wel vanuit verskillende oorwegings (vgl Lester \& Hefley, 1980; Singer \& Wells, 1984). Smit (1985:168-169), Van Niekerk (1994:25) en Jochemsen en Glas (1997:194, 219) wys kloning af, veral vanuit die huweliksetiek (vgl. Heyns, 1986:325). Douma (1989:134-136) keur dit vanuit ' $n$ bepaalde mensbeeld (hoogmoed) af, terwyl Kuitert (1989:222) en Rae (1996:177) dit afwys omdat dit 'n aantasting van die uniekheid van die individuele mens sal meebring. Geisler (1989:20-21) en Schulze (1997:20-21) verwerp dit vanuit die Godsleer - die mens probeer hier immers God speel. ${ }^{4}$ Feindberg en Feindberg (1993:252) oordeel meer genuanseerd: kloning word afgewys ten opsigte van enkelouers en homoseksuele persone asook by orgaanoorplantings maar hulle aanvaar dit (tentatief) ten opsigte van infertiele heteroseksuele pare.

Die groot vraag is hoe kloning beoordeel moet word: Waar kom die kriteria vir beoordeling vandaan? Van God? Van die mens? Van die natuur? Dis hierdie kernvrae wat ons tans gaan besighou.

\section{Evaluering}

\subsection{Inleidende opmerkings}

Ons is tans by die heel moeilikste deel van hierdie besinning: Hoe moet kloning beoordeel word? Vrae soos die volgende va tans ons aandag: Watter beoordelingskriteria is ten opsigte van hierdie vraagstuk toepaslik? Waar word hierdie kriteria gevind? Hoe moet hierdie kriteria ten opsigte van die vraag na kloning aangewend word? Tot watter gevolgtrekking moet in hierdie opsig geraak word? Die vraag na beoordelingskriteria is nie ' $n$ neutrale vraag nie, maar hang saam met 'n lewens- en wêreldbeskouing, met die (filosofiese) paradigma wat iemand bewustelik of onbewustelik aanvaar. "Ethical decisions are not made in a vacuum; they are made within a world view" (Geisler, 1989:173). Volgens

4 Die studie van J. Douma oor Medische ethiek (1997:38-56) gee aandag aan die Sknfberoep in die mediese etiek Hy bespreek kortliks die vraagstuk van kloning (p. 166-168) en wys op die belangrikheid van mensvisie (p. 166-168). Douma spreek hom uit teen eugenetiek as proses van sonde-oorwinning en selfvervolmaking (p. 165-166), maar merk op dat die argument dat kloning die uniekheid van 'n persoon aantas, nie volledig opgaan nie (vgl tweelinge - p 165). Die mens is rentmeester en mag nooit Skepper word nie (p. 168-171) Douma kom egter nie tot 'n finale konklusie ten opsigte van kloning nie. 
Geisler (1989:192) staan by die vraagstuk oor kloning veral twee wêreldvisies teenoor mekaar, naamlik die humanistiese en die Christelike

Die besinning wat tans volg, beweeg ietwat op 'n syspoor maar is onmisbaar, gesien die moeilikheidsgraad van die vraagstuk.

\subsection{Waar kom die beoordelingskriteria vandaan?}

Beoordelingskriteria in die bio-etiek kan op ten minste drie plekke gesoek word, naamlik by God, by die natuur of by die mens self.

\section{- 'n Naturalistiese benadering}

In 'n naturalistiese benadering word die kriteria uit die natuur of die gebeure afgelei - vergelyk in hierdie verband die gebruik wat die Rooms-Katolieke moraalteologie van 'n natuurlike etiek maak. Dit bied egter nie 'n finale oplossing nie aangesien dit nie die feit van die sonde in die lewe genoegsaam verreken nie sodat die verlossingswerk van Christus en die vernuwingswerk van die Heilige Gees onderwaardeer word. Feite-oordele mag nie tot waarde-oordele verhef word nie; wat kan, mag nie noodwendig nie, permissie val nie saam met kompetensie nie; wat gebeurlik is, is nie noodwendig aanvaarbaar/toelaatbaar nie; wat moontlik is, is nog nie behoorlik nie; nie alles wat tegnies moontlik is, is moreel geoorloof nie (Stob, 1978:220; Küng, 1983:169; Kuitert, 1989:223-225): “Ability' does not imply morality" (Geisler, 1989:178). Daar moet noukeurig tussen 'n preskriptiewe etiek en deskriptiewe etiek onderskei word.

Hier beweeg ons op die besonder moeilike spanningsveld tussen werklikheid en verantwoordelikheid, tegniek en etiek.

- 'n Humanistiese etiek

'n Tweede moontlikheid is om die kriteria in die mens te soek soos in die humanistiese etiek en outonome moraal gedoen word - 'n moontlikheid wat veral deur H.M. Kuitert in sy rasionalistiese denkwyse ontgin word. Die vraag is egter of so 'n kosmiese kompas 'n veilige wegwyser in die labirint van mediese etiek kan wees. Wat daarvan as individuele mense mekaar in die mediese etiek weerspreek? Moet dan met die grootste gemene deler van menslikheid gewerk word (vgl. Kant)? Maar wie bepaal dit? Kuitert (1989:219) werk hier byvoorbeeld met "twee simpele waarhede" of "controle-punten" (naamlik menswaardigheid en doel), maar die vraag is waar Kuitert hierdie simpele waarhede vandaan haal. Kan daar ooit sonder objektiewe beginsels en norme in die etiek gewerk word? Kan etiek ooit anders as normatiewe etiek wees?

Sonder twyfel is die (welsyn van die) mens in die etiek van die allergrootste belang - soos later sal blyk. Ook vir die Christelike etiek is dit belangrik dat aan álle mense goed gedoen word (Gal. 6:10) en dat "goeie werke" omskryf kan 
word as dit wat "goed en nuttig" is vir die mense (Tit. 3:8). Die Christelike etiek onderskei hom egter van die humanistiese etiek daarin dat die mens nie los van God ter sprake gebring word en so verabsoluteer word nie.

\section{- Christelike benadering}

Dit is ongetwyfeld waar dat die vraag of kloning moreel geoorloof is of dan nie, 'n vraag is oor die mens en mensbeskouing (antropologie). Die vraag oor wie en wat die mens is, kan egter nie beantwoord word sonder die vraag na wie en hoe God is nie, aangesien God die mens (na sy beeld) geskape het (vgl. Van Wyk, 1996:24-25, met verwysings). Die mensleer rus op en vloei voort uit die Godsleer (vgl. Stob, 1978:223-227; Smit, 1988; Cameron, 1991:172-174). Daarom is ' $\mathrm{n}$ Teologiese benadering noodsaaklik.

Wie die vraag na kloning, dus die vraag na die mens, sy voortplanting en sy toekoms, wil beantwoord, kan dit nie buite God - sy Skepper - om doen nie. Vanweẻ die waarde- en normlading wat noodwendig gepaard gaan met alle medies-etiese besinning, behoort die godsdienstige oorsprong van waardes en norme altyd in berekening gebring te word (vgl. Küng, 1983:173; Douma, 1991a:70). Word die vraag gestel wat 'n goeie werk is, moet daarop geantwoord word: dit wat "uit 'n ware geloof, volgens die wet van God en tot sy eer gedoen word" (HK 33:91). Anders gesê: kenmerkend van die Christelike lewe is geloof in Christus, sonde-ontvlugting, die najaag van geregtigheid, liefde vir God en die naaste en kruisiging van die sondige menslike natuur (NGB 29).

Teenoor 'n outonome etiek kies ons welbewus vir 'n teonome etiek. Dit is 'n lewensbeskoulike keuse - soos immers die keuse vir 'n outonome etiek. Ons oefen hierdie keuse uit omdat die sonde die denkvermoë van die mens grondig aangetas het (DLR 3/4). Dit gaan in die etos oor die doen van wat "goed en reg" is in die oë van die Here God (Deut. 12:28) en om tussen "goed en kwaad" te onderskei (Heb. 5:14), maar oor hiérdie soort kennis beskik net God in finale instansie. Vir die mens om self tussen goed en kwaad te probeer onderskei, is die oersonde van die mens (Gen. 3:5).

Ons het aangevoer dat die mensvraag die Godsvraag impliseer. Oor God kan ons egter nie praat buite sy openbaring in die Woord (Bybel) om nie. Sonder twyfel het Hy Hom ook in die skepping geopenbaar, maar sy duidelikste en volmaakste openbaring vind ons in sy Woord (NGB 2). Ons kan nie ontken nie dat God in sy algemene goedheid wel kennis en wyshede aan alle mense skenk (vgl. Douma, 1991b:69-70) - vergelyk slegs die hoë denkvlugte wat in die etiek van Aristoteles en Kant aangetref word - maar menslike wysheid kan nie ' $n$ veilige kompas wees nie (Hoek, 1985:137). Die rigting moet van buite - van God - aan die mens aangedui word. Die Bybel is gegee vir sowel die verhaal as die moraal. 
Maar hoe gemaak as die Bybel nie direk en ondubbelsinnig 'n antwoord gee op alle etiese vrae nie, ook nie op die vraag na kloning nie? Die Bybel kan wel as handleiding vir die etiek dien maar tog nie as resepteboek nie?

Die vraag na die Skrifberoep in die etiek is geen maklike saak nie (Hoek, 1985:137-139) en het al baie besinning opgeroep (vgl. Van Wyk, 1986:15, met verwysings). Hoek (1985:140) wys daarop dat die onderskeiding tussen burgerlike, seremoniële en morele wette onvoldoende is (vgl. NGB 25) en dan bespreek hy J.R. McQuilkin se sewevoudige Bybelse hermeneutiese filters (Hoek, 1985: 141-142). In hierdie verband kan ook gedink word aan Heyns (1982:159-170) se tien Bybelse koördinate of Van Wyk (1986:16-17) se dertien hermeneutiese riglyne. Uit hierdie diskussie word duidelik dat onderskei moet word tussen (historiese) gestalte en (aktuele) gehalte van die Bybelse imperatiewe. Terwyl weggestuur word van 'n biblisisties-fundamentalistiese Skrifgebruik, word voluit gekies vir 'n Skrifgebruik wat erns maak met die gesag van die Skrif, maar daarmee saam ook met die spesifieke aard van daardie gesag. Moontlik kan die volgende onderskeiding hier van hulp wees: 'n Saak is Skriftuurlik wanneer dit direk in die Skrif bespreek en besleg word, maar dit is Skrifmatig wanneer dit nie direk nie, of in geheel nie, in die Skrif ter sprake kom maar tog korreleer met die gees en rigting van die Skrif. Alle gebooie - en vertolkings - moet egter in die bloed van Christus gedoop word, deur sy liefde gekleur en deur sy kruis en opstanding heengehaal word (Hoek, 1985:142), dit wil sê, met Christus in verband gebring word (vgl. Jochemsen \& Glas, 1997:196).

Die Bybel bevat nie 'n uitgewerkte etiek en norm-sisteem wat op kasuistiese wyse toegepas kan word nie. Ten einde die probleem van (historiese) bemiddeling te oorbrug, word in die gereformeerde etiek wyd gebruik gemaak van die onderskeiding tussen geopenbaarde norme (wat onvoorwaardelik, algemeen en totaal geldig is), gepositiveerde norme en kontingente norme (Heyns, 1982: 180-187) 5 . Soms word ook wel van grondnorme en afgeleide norme gepraat of ook van (onveranderlike) beginsels en (veranderlike) norme.

In hierdie artikel word die onderskeiding van (a) basisprinsipes, (b) grondnorme en (c) toegepaste norme gehanteer. Onder die basisprinsipes word verstaan daardie onveranderlikes wat vir die Christelike etiek van fundamentele belang en deurslaggewende betekenis is. Voorbeelde hiervan is die volgende:

- word 'n daad tot eer van God gedoen? (vgl. 1 Kor. 10:31; 1 Pet. 4:11);

- word 'n daad volgens die wil (gebod) van God uitgevoer? (vgl. Rom. 12:2; Kol. 1:9; 1 Tess. 4:3);

$5 \quad$ Vgl Wurth, 1957:159-191; Stoker, 1961:220-223, Van der Walt, 1979:31-38, Duvenage. 1981 93-109; Van Wyk, 1986:7-8; 35; De Bruyn, 1993:2-6 
- word Christus daarin nagevolg? (vgl. Joh. 13:15; 1 Joh. 2:6);

- geskied dit onder leiding van die Heilige Gees? (vgl. Rom. 8:6; Ef. 5:17-18);

- dien dit die voortgang van die koninkryk van God (en tot afbraak van die "ryk" van duisternis)? (vgl. Matt. 6:33) (vgl. Ouweneel, 1975:111);

- dien dit die welsyn van die kerk van God?

- word dit uit geloof gedoen? (Rom. 14:23);

- word dit uit liefde gedoen? (1 Kor. 13).

- reflekteer die mens in sy optrede die karakter van God? (vgl. Matt. 5:48; Luk. 6:36; 1 Pet. 1:15).

As grondnorme geld onder andere sake soos naasteliefde, geregtigheid, getrouheid, vryheid, waarheid, menswaardigheid ensovoorts (vgl. ook die verskeie deugdereekse wat in die Nuwe Testament aangetref word, soos in Gal. 5:22 en Fil. 4:8).

Met toegepaste norme word bedoel die aktualisering van grondnorme in wisselende lewensituasies. Wat laasgenoemde betref, moet die gevare verbonde aan 'n oordrewe situasie-etiek sorgvuldig vermy word waar die norm uit die situasie afgelei in plaas van in die situasie ingedra te word - soos die bronsel in die eisel. Die norm moet die situasie bepaal en (transformeer) en nie die situasie die norm nie (contra Küng, 1983:173-174).

Die vraag wat tans beantwoord moet word, is die vraag watter beoordelingskriteria van toepassing is op die mediese etiek in die algemeen en op kloning in die besonder.

\subsection{Watter beoordelingskriteria is in die mediese etiek toepaslik?}

In hierdie verband is dit insiggewend om te gaan kyk na watter kriteria ' $n$ aantal navorsers oor hierdie onderwerp na vore gebring het. Ouweneel (1975:113-118) hanteer in hierdie opsig "drie steunpilare", naamlik die Goddelike skeppingsorde (wat nie oorskry mag word nie), teonomie/Christonomie en eskatologie (veral Gods oordeel). Velema (1985:73-77) noem drie grondprinsipes, te wete eerbied (vir die mens), liefde en diens. Geisler (1989:181-182) voer vyf basiese prinsipes aan die soewereiniteit van God, die waardigheid van die mens, die heiligheid van die lewe, die sterflikheid van die lewe en liefde teenoor die naaste/lewe. Douma (1991:76-79) verwys na vier prinsipes waarop hy dan bepaalde korreksies aanbring (Douma, 1991a:78-81), naamlik outonomie (wat hy vervang met 
verantwoordelikheid), non-maleficentia (iemand nie kwaad aandoen nie), beneficentia (aan iemand goed doen; vergelyk salus aegroti summa lex $=$ die heil van die sieke is die hoogste wet) en geregtigheid (ten opsigte van die aanwending van middele) (vgl. breedvoerig Beauchamp \& Childress, 1989). Toegepas op kloning kom die vraag by laasgenoemde dan na vore of met kloning (as waarskynlike rykmansbedryf) voortgegaan moet word terwyl miljoene mense jaarliks van honger sterf en nie oor die mees basiese mediese dienste beskik nie.

Ongetwyfeld is naasteliefde die grondnorm in die etiek. Dit kan getipeer word as "die matrix van alle normativiteit voor de mens" (De Graaf, 1961:49), "de hoofdzaak en de kem van alle moraliteit", hoewel nie die totaal daarvan nie (Heering, 1969:69). Liefde is die hoogste en omvattendste norm vir die etiese (Heyns, 1982:230; 1989:150), dit is die norm vir en kern van alle moraliteit (Heyns, 1982:230). Die liefde kom die primaat toe, hoewel nie die monopolie (en eksklusiwiteit) nie (Velema, 1990:89, met verwysing na Schrage). Die liefde is immers die vervulling van die wet en nie die vervanging daarvan nie (Velema, 1990:86-89). Liefde is die samevatting van die wet en nie die eliminering daarvan nie (Matt. 22:40).

In die Skrif self word op hooggestemde wyse oor die (naaste-) liefde gehandel. Die liefde word beskryf as "die grootste" van al God se genadegawes aan die mens (1 Kor. 13:13), as "die neerslag" van die wet en die profete (Matt. 7:12), as "die volle uitvoering van die wet" (Rom. 13:10), as "die samevatting" van die hele wet (Gal. 5:14; vgl. Matt. 22:40) en as "die wet van die koninkryk van God" (Jak. 2:8). Vandaar die besondere uitspraak in Rom. 13:8. "Julle moet niemand iets verskuldig wees nie, behalwe om mekaar lief te hê. Wie sy medemens liefhet, voer die hele wet van God uit." Soos bekend, gaan dit hier oor liefde of agape in sy spesifiek Bybelse betekenis van selfofferende en selfoorgewende liefde aan die ander. Die nuutheid van die nuwe gebod wat Christus gegee het, is in sy radikaliteit geleë: Ons moet mekaar liefhê soos Christus ons liefgehad het, dit wil sê tot in die dood (Joh. 13:34). "Gods liefde in Christus is basis en norm voor de liefde dat Hij van ons vraagt" (Velema, 1990:87).

Die liefdesgebod mag egter nie op eksklusivistiese wyse gehanteer word ten koste van die Tien Gebooie nie (vgl. Matt. 24:12). Soos wat die evangelie in die wet reeds in die Ou Testament aanwesig is, so is ook in die Nuwe Testament die wet in die evangelie aanwesig. Jesus skaf nie die wetseise af nie (Mark. 10:19), maar Hy hanteer die liefdesgebod as hermeneutiese prinsipe vir die verstaan van die gebooie (Mark. 2:27). Die liefde is die kompas, maar die gebooie is die landkaart (Douma, 1980:93). Alle menslike handelinge, ook dié van die genetikus en embrioloog, moet uit en in liefde geskied. Die wet van die liefde hef die liefde vir die wet nie op nie. Sonder liefde kan niemand die Here behaag nie. Die liefde doen die naaste geen kwaad nie; die liefde laat die naaste blom; die liefde versag pyn en verhelp lyding 
Die kriteria wat aan die begin van $\mathbf{5 . 3}$ genoem is, is almal op een of ander wyse relevant, maar die hoogste grondnorm en samevatting van alle etiese norme is die (naaste-) liefde - maar dan as liefde wat gewortel is in geloof in, liefde vir en gehoorsaamheid aan God.

Die vraag wat nou gehanteer moet word, is hoe kloning in die lig van al bogenoemde gegewens konkreet beoordeel moet word.

\subsection{Hoe moet kloning konkreet beoordeel word?}

Drie kernvrae moet hier bespreek word, naamlik in verband met die Godsleer, die mensleer en die huweliksetiek.

\section{- Die vraag in verband met die Godsleer}

Die groot vraag is of die mens nie ten opsigte van kloning probeer om God te speel nie (vgl. Douma, 1989:136; Geisler, 1989:190; Rae, 1996:175; anders by Kuitert, 1989:218, 222-223; De Knijff, 1997:258). Skep die mens nie deur kloning mense na sy (die mens se) beeld en ontken hy nie daarmee dat God die mens na sy (God se) beeld geskape het nie? Is kloning nie 'n daad van uiterste hoogmoed waarin die mens "soos God" probeer wees nie?

Hierop moet geantwoord word dat die embrioloog nie nuwe mense skep nie (vgl. Schulze, 1997:20-21), maar dat hy met voorhande materiaal (eisel en liggaamsel) werk en dat hy bestaande menslike selle manipuleer. Die mens kon (nog) nie daarin slaag om mense te maak nie. Verder moet verreken word dat daar by elke nuwe mediese ontwikkeling - vgl. bloedoortapping, kunsmatige inseminasie, orgaanoorplanting - morele weerstand opgeroep word, wat dan as etiese grensoorskryding beskou word - 'n benadering wat selfs vandag nog by minderheidsgroepe aangetref word. Sonder twyfel kan mediese navorsing in hoogmoed, selfoorskatting en outonomie teenoor God ondemeem word, maar dit kan ook in diepe ootmoed, afhanklikheid en onderdanigheid teenoor Hom gedoen word. Ook in die mediese etiek moet die mens sy kultuurmandaat of roepingsopdrag uitleef (vgl. Rae, 1996:176) en moet hy beeld van God wees, dit wil sê die heerskappy van God oor die skepping reflekteer. Hierdie opdrag van God moet die mens uitvoer nié téénoor God nie maar in gemeenskap met en in afhanklikheid van God en binne die raamwerk van die gebod van God (vgl. Scorgie \& Jones, 1997:670672).

\section{- Die vraag in verband met die mensleer}

Die tweede vraag hou verband met die mensleer en raak sake soos die volgende: tas kloning nie die uniekheid van die individuele persoon aan nie? Wat van die siel van die mens? Kan kloning gesien word as daad van naasteliefde? 
Hierop moet geantwoord word dat kloning inderdaad 'n ingreep is op die uniekheid van 'n persoon, maar dit hoef nie 'n onoorkomelike probleem te skep nie. Hoewel 'n gekloonde persoon geneties identies behoort te wees aan die persoon wat die liggaamsel skenk, is dit ook waar dat persoonlikheidsontwikkeling medebepaal word deur sake soos opvoeding, ervaring en ander omstandigheidsfaktore. Hierdie waarheid kan reeds by identiese tweelinge opgemerk word: hulle is eenders maar tog anders.

Die vraag of kloning nie die (skepping van die) siel van die mens in gedrang bring nie, is begryplik, maar is alleen belangrik indien die mens volgens die GrieksPlatoniese mensbeeld benader word (vgl. Van Wyk, 1993:5-20, met bronverwysings). Hiervolgens bestaan die mens uit twee dele, met die siel as die belangrikste en onsterflike deel; die siel, wat van ewigheid bestaan, verenig hom dan op een of ander stadium met die liggaam van die mens. Selfs in die gereformeerde teologie is lank gestry oor die vraag of die siel by elke mens afsonderlik geskep word (kreasianisme) en of die siel langs die weg van natuurlike voortplanting ontstaan (tradusianisme). Hierdie (valse) probleemstelling is egter laat vaar omdat daarmee 'n buite-Bybelse probleem in die Bybel ingedra is waarop die Bybel eenvoudig nie 'n antwoord gee nie. As die Bybel praat van die mens as gees, siel en liggaam. (1 Tess. 5:23), dan word daarmee nie drie gefragmenteerde komponente (soos motoronderdele) bedoel nie maar drie dimensies van die een mens. Die Bybel lê 'n swaar aksent op die eenheid van die mens. 'n Gekloonde mens kan nie 'n "siellose" mens wees nie, maar behoort volledig mens te wees, beeld van God, oop vir die evangelie en die verbond van God (vgl. Scorgie \& Jones, 1997:668-669).

Binne hierdie konteks kan kloning as daad van naasteliefde beskou word - aan kinderlose egpare. En daarmee het ons by 'n kernprobleem gekom.

\section{- Die vraag oor huweliksetiek}

Die derde vraag raak die huweliksetiek. Indien kloning, as vorm van buiteseksuele, buite-manlike en buite-huwelikse voortplanting, universeel en onbeperk toegepas sou word, dan sal dit die huwelik as instelling van God en as natuurlike voortplantingsinstituut totaal uit sy voeë lig en uiteindelik oorbodig maak. "Once a population was built up through cloning, normal procreation (through the fusion of two half-sets of genes) would no longer be safe means for partners to generate offspring" (Scorgie \& Jones, 1997:66). Dit sal enkelouerskap op ongekende wyse promoveer en veroorsaak dat die meeste kinders sonder 'n vader of moeder en buite gesinsverband groot word.

Hienteenoor is daar die moontlikheid dat kloning binne huwelikskonteks - soos kunsmatige inseminasie met eggenootsaad (KIE) - toegepas kan word en wel in die geval van kinderlose egpare, byvoorbeeld waar die man se geslagsorgane 
vermink of verwyder is. In so 'n geval sou van die liggaamselle van die man gebruik gemaak kon word. So benader, kom kloning ter sprake as uitsonderingsgeval en nie as reël nie. Die etiek ken immers byna orals die "kategorie van uitsondering" - vergelyk byvoorbeeld die uitsonderings by aborsie, doodslag, egskeiding, Sondagviering.

Daar is tans egter net te veel van die reeds genoemde morele en etiese vrae onbeantwoord om kloning as algemeen aanvaarde praktyk goed te keur.

\subsection{Voorlopige samevatting}

Die feit dat hier tastend na antwoorde gesoek word, hang saam met die moeilikheidsgraad van die tema. Dit is in elk geval nie 'n tema wat op individualistiese wyse in 'n studeerkamer beslis kan word nie, maar behoort indringend aan groepbespreking, veral binne gemeentelike konteks (Hoek, 1985:144; Grewel, 1988:122), onderwerp te word. ${ }^{6}$

Daar bestaan drie moontlike antwoorde op die vraag na kloning: eerstens: dit mag altyd; tweedens: dit mag nooit, en derdens: dit mag soms. Self soek ek na 'n oplossing in die derde rigting. Sodoende word gepoog om tussen die twee uiterstes van fundamentalisme/negativisme (niks mag) en relativisme/positivisme (alles mag) deur te stuur.

'n Antwoord word in die volgende rigting gesoek:

- Kloning by diere lê nie op dieselfde vlak as kloning by die mens nie en skep minder etiese probleme as in die geval by die mens. Daarmee is natuurlik nié gesê dat eksperimente met diere geen morele grense ken nie.

- Kloning moet as algemene praktyk - dus buite die huwelikskonteks om afgewys word vanweë die genoemde swaarwegende morele probleme daaraan verbonde.

- Kloning kan moontlik op selektiewe en gereguleerde wyse binne huwelikskonteks oorweeg word, byvoorbeeld in geval van infertiliteit of wanneer die man vanweë 'n ongeluk of operasie (kanker) sy geslagsdele verloor het. Kinderopvoeding in gesinskonteks bly dus behoue. Genetiese identiteit impliseer ook nie 'n $100 \%$ persoonlikheidsidentiteit nie, aangesien laasgenoemde - soos by identiese tweelinge ook die geval is - medebepaal word deur 'n hele reeks eksterne faktore, soos reeds eerder vermeld. Die argument dat kloning die uniekheid van 'n persoon sal aantas, geld veral wanneer kloning universeel op aanvraag toegepas word.

6 Die neerslag van hierdie artikel berus ook nie bloot op studieresultate van die skrywer nie, maar op wydverspreide gesprekke met kundiges én onkundiges 
- Indien daarin geslaag kan word om kloning op moreel verantwoorde wyse vir terapeutiese doeleindes aan te wend, byvoorbeeld vir orgaanontwikkeling (om sodoende orgaanverwerping by oorplanting uit te skakel), kan dit 'n bydrae lewer tot verhoogde lewenskwaliteit en leedversagting.

- Splyting van 'n embrio wat deur kunsmatige inseminasie (uit 'n eisel en saadsel) (KIE) ontwikkel is, lewer oor die algemeen minder etiese probleme as kloning.

\section{Konkludering: voorlopige etiek}

Etiek is in tweërlei sin van die woord voorlopig (Heering, 1969). Eerstens, omdat etiese antwoorde, veral oor moeilike temas, dikwels 'n voorlopige, voorfinale en onaf karakter openbaar. Ook die etikus ken ten dele (1 Kor. 13:12) en beskik nie onmiddellik oor finale antwoorde nie. Ook die etiek weet van 'n kenteoretiese voorlopigheid. Tweedens, omdat die etiek altyd moet probeer om voorloper, voortrekker en baanbreker te wees. Die etiek mag nie daarin berus om voortdurend agterryer van die (mediese) tegnieke te wees nie. So 'n taak is vir die teoloog dikwels besonder moeilik en verg veel navorsing, gesprek en gebed.

Die antwoord wat in hierdie artikel aangebied word, moet binne hierdie konteks gesien word. Dis 'n voorlopige besinning en staan wyd oop vir kritiek en weerspreking. Andersyds probeer dit rigting aanwys vir 'n pad wat nog gekarteer en gebaan moet word.

\section{Bronnelys?}

BEAUCHAMP, T.L \& CHILDRESS, J F 1989 Principles of biomedical ethics. New York Oxford University Press

BEAUCHAMP, T.L. \& McCULLOUGH, L.B. 1984 Medical ethics: The moral responsibilities of physicians Englewood Cliffs : Prentice-Hall

CAMERON, N.M. de S. 1991. The new medicine: Life and death after Hippocrates. Wheaton Ill : Crossway Books.

COHEN, J \& TOMKIN, G. 1994. The science, fiction and realities of embrio cloning Kennedy Institute of Ethics Joumal, 4(3) 193-203, Sept

DE BEAUFORT, I D. \& DUPIUS, H.M., red 1988 Handboek gezondheidsethiek. Assen Van Gorcum.

DE BRUYN, P J 1993. The ten commandments. Midrand : Varia.

DE GRAAF, J 1961. De ethiek van het immoralisme. Nijkerk : Callenbach

DE KNIJFF, H W. 1997. Klonen: copernicaanse revolutie? Kerk en theologie, 48(3) 254 259.

DIXON, P 1993. The genetic revolution: Today's dream or tomorrow's nightmare? Eastbourne : Kingsway Publications.

7 Dank word uitgespreek teenoor ds A.L Rheeder van Pietersburg asook prof A.A van Niekerk van Stellenbosch wat my aandag op enkele belangnke bronne gevestig het 
DOUMA, J. 1980. Verantwoord handelen: Inleiding in de christelijke ethiek. Amsterdam : Ton Bolland.

DOUMA, J. 1989. Milieu en manipulatie. Kampen : Van den Berg

DOUMA, J. 199la. De politieke verantwoordelijkheid voor de gezondheidszorg met betrekking tot de ethische grenzen (In Post, D., et al. De grenzen bereikt. Over ethische vragen bij financiële begrenzing van de gezondheidszorg. Amsterdam : Buijten \& Schipperheijn p. 75-89.)

DOUMA, J. 199lb. Het proprium in de christelijke moraal en ethiek. (In Van Genderen, J, et al., red. Ten dienste aan het Woord: Opstellen aangeboden aan prof. dr. W.H. Velema Kampen : Kok. p. 55-73)

DOUMA, J. 1997. Medische ethiek. Kampen : Kok.

DU TOIT, D. 1989. Antropologie en embriologie. (In Theron, P.F. \& Kinghorn, J, red. Koninkryk, kerk en kosmos: Huldigingsbundel ter ere van prof. WD Jonker Bloemfontein : Pro Christo. p. 101-111)

DUVENAGE, B 1981. Roeping en wetenskap: Handleiding vir wetenskapsleer. Potchefstroom : Pro Rege.

EBON, M., ed 1978. The cloning of man, a brave new hope - or horror. New York : New American Library.

FEINDBERG, J.S. \& FEINDBERG, P.D 1993. Ethics for a brave new world. Wheaton III Crossway Books.

GEISLER, L.G. 1989. Christian ethics: Options and issues. Grand Rapids : Baker.

GREWEL, H. 1988. Brennende Fragen christlicher Ethik Gottingen : Vandenhoeck \& Ruprecht

HEERING, H.J. 1969. Ethiek der voorlopigheid. Nijkerk : Callenbach.

HEYNS, J.A. 1982. Teologiese etiek 1. Pretoria : NG Kerkboekhandel

HEYNS, J.A. 1986. Teologiese etiek 2/1 Pretoria : NG Kerkboekhandel.

HEYNS, J A 1989. Teologiese etiek 2/2. Pretoria : NG Kerkboekhandel.

HOEK, J. 1985. De Bijbel as bron van nomen - over de fundering van ons christelijk handelen. Radix, 11:133-144

HUXLEY, A. 1932 [1969]. Brave new world. Harmondsworth : Penguin.

JOCHEMSEN, H. \& GLAS, G. 1997 Verantwoord medisch handelen: Proewe van een christelijke medische ethiek Amsterdam : Buijten \& Schipperheijn.

JONSEN, A. 1990. The new medicine and the old ethics. Cambridge Ma : Harvard University Press.

KRAUTHAMMER, C 1997. A special report on cloning. Time, 149(10):46-47, March

KUITERT, H.M. 1989. Mag alles wat kan? Ethiek en medische handelen Baarn : Ten Have

KUNG, H. 1983. Eeuwig leven? Hilversum : Gooi \& Sticht

LEACH, G. 1970. De biocraten: Nieuwe heersers over leven en dood. Leiden : Sijthoff

LESTER, L.P \& HEFLEY, J C 1980. Cloning? Miracle or menace? Wheaton : Tyndale House.

LINDEBOOM, G.A. 1960. Opstellen over medische ethiek. Kampen : Kok

MACKLIN, R. 1994. Splitting embryos on the slippery slope: ethics and public policy. Kennedy Institute of Ethics Joumal, 4(3):209-225, Sept

MEILANDER, G. 1997. Bioethics: A primer for Christians. Carlisle : Patemoster

NASH, JM 1997. The age of cloning. Time, 149(10) 48-51

NELSON, J B \& ROHRICHT, J.A.S. 1984. Human medicine: Ethical perspectives on today's medical issues. Minneapolis: Augsburg Publishing House.

OUWENEEL, W J. 1975. Operatie supermens: Een bijbels-biologische blik op de toekomst Amsterdam : Buijten \& Schipperheijn. 
RAE, S.B. 1996. Brave new families: Biblical ethics and reproductive technologies. Grand Rapids : Baker.

ROBERTSON, J.A. 1994. The question of human cloning. Hastings Center Report, 24(2):614, March-April.

RORVIK, D. 1978. In his image: The cloning of man London : Hamilton.

SCHULZE, L.F. 1997. Kloning - kan die mens regtig lewe skep? Die Kerkblad : 20-21, April, 23.

SCORGIE, G G. \& JONES, C.F.E. 1997 Human life is not sheep: an ethical perspective on cloning Journal of the Evangelical Theological Society, 40(4):663-679, Dec

SINGER, P. \& WELLS, D 1984. The reproduction revolution: New ways of making babies Oxford : Oxford University Press.

SMIT, J.H. 1985 Etos en etiek. Bloemfontein : Patmos

SMIT, J.H. 1988. Die betekenis van 'n Christelike mensbeskouing vir die gesondheidswetenskappe. Potchefstroom : PUCHO.

SMIT, K. 1991. Persoonwees en die morele status van die menslike embrio Koers, 56(3):313337, September

SMITH, H.L. 1970. Ethics and the new medicine. Nashville : Abingdon Press.

SPORKEN, P. 1969. Voorlopige diagnose: Inleiding tot een medische ethiek Utrecht : Ambo.

STOB, H. 1978. Ethical reflections: Essays on moral themes Grand Rapids : Eerdmans

STOKER, H G 1961. Beginsels en metodes in die wetenskap. Potchefstroom : Pro Rege

TAYLOR, G.R 1968. De biologische tijdbom. Amsterdam : Elsevier

VAN DEN BERG, J.H 1969. Medische macht en medische ethiek Callenbach : Nijkerk

VAN DER WALT, S.P. 1979. Gods Wet en "die ander wet". In die Skriflig, 13(50):28-44, Junie.

VAN NIEKERK, A.A. 1994. Kloning: genetiese kopiëring Die Voorligter, 24-25, Sept

VAN NIEKERK, A. 1997. Ou wyn in nuwe vate: Werk die ou etiek vir die nuwe vate? Koers, 62(3) 255-276, Sept.

VAN WYK, J.H. 1971. Etiek in 'n eeu van tegnologie en tegnokrasie Johannesburg. (Skripsie - PUCHO)

VAN WYK, J H 1986. Gesindheid en gestaite Pretoria : NG Kerkboekhandel

VAN WYK, J.H. 1993. Homo Dei: 'n Prinsipiële besinning oor enkele mensbeskouings, waaronder dié van Calvyn. In die Skriflig, Supplementum 1.

VAN WYK, J.H. 1996. Antropologie en pastoraat: 'n teologiese verkenning. In die Skriflig, 30(1) $21-36$

VELEMA, W.H. 1985. Grondprincipes van medische ethiek (In Strijbos, S., red Nieuwe medische ethiek. Amsterdam : Buijten \& Schipperheijn. p 66-77.)

VELEMA, W.H. 1990 Oriëntatie in de christelijke ethiek. 's-Gravenhage : Boekencentrum WURTH, G.B. 1957. Het christelijk leven: Grondlijnen der ethiek. Kampen : Kok 
